\title{
Strengthening Nigeria-India Intelligence Cooperation: Much To Do In Fighting Boko Haram
}

\author{
Ghazali Bello ABUBAKAR ${ }^{1}$ \\ 1Department of Political Science, Sokoto State University, Sokoto, Nigeria
}

Keywords: Boko Haram, Cooperation, Insurgency, Intelligence, IndiaNigeria, Jihad, Indian Mujahedeen.

\begin{abstract}
Purpose of the study: This paper examines the span period of time that has passed since when terrorist group, loosely known as Boko Haram otherwise Jama'at ahlus-Sunnah lid-Da'awat wal-Jihad (the people committed to the teaching of Prophet, for provocation and Jihad), launched atrocities against innocent civilians mainly in the dominant Muslim northeast Nigeria as an ostensible process of paving the way for the implementation of Shari'ah law in the country.
\end{abstract}

Methodology: Qualitative data analysis is applied to conduct this research. Books, journals, and research reports compiled on Boko Haram atrocities were consulted as sources of information. The IndoNigeria bilateral ties on the economy and intelligence guide this research to the conclusion.

Finding: On one side, this study concludes that the fertile ground of the ongoing crisis is championed by the rampant poverty, disparity in the distribution of wealth, and a high rate of illiteracy. While in the other, it finalizes that the long-term experience India has on terrorist-related activities within its territories equip her to develop soft landing-approaches that hold various attacks carried out by the insurgents so much undermined. It, nevertheless, finalizes that the alleged relationship between the sect and some top political elites and even some higher-ranking security officers began against a backdrop of faceless insurgents. However, Nigeria's domestic pressures, including poverty, illiteracy, religio-tribalism as well as regional sentimentalism, among other factors that bolster the heavyweight size and bulky of the insurgency in the region.

Application: This work is most usefully crucial for both students and readers those that develop an interest in African Studies, International Relations, and Conflict resolution as well.

Novelty/Originality: Boko Haram claims that waging war against the current leadership of Nigeria seized by corrupt individuals and forged Muslims is obligatory. As India faces similar threats and thus passes through experience of dealing with terror insurgents, this paper aims at exploring how India and Nigeria can multiply efforts to fighting the Boko Haram sect.

\section{INTRODUCTION}

As multicultural environments, both India and Nigeria had since independence, undergone several severe tribal, semitribal, and religious conflicts in many places of their localities like Uttar Pradesh, Gujarat, Assam, and Punjab in India, Plateau, Kaduna, Kano, Taraba and elsewhere in Nigeria. Ethno-religious differences instigated the outbreak of violence in Nigeria for tens of years. The government efforts to overcome such atrocities, particularly the currently ongoing strife started during the late President Yar' Adua and continued throughout the President Goodluck Ebele Jonathan administration seem inadequate and ineffective compared to the sample level of the insurgencies witnessed so far. Not fully terminated, but the situation, during Buhari's first tenure (2015-2019), seems feebly weak - with a lot to invest yet - compared to the previous times.

With the inauguration of the new government under the leadership of the former military head of States, Major-General Muhammad Buhari (rtd.), the dimensional structure towards fighting the insurgencies in Nigeria takes another measure. The structural context of Boko Haram completely enthralled many analysts to wonder whether the roots and causes of the violent attack carried out by the Islamist militants are religious or political ones. Precisely, some pieces of evidence indicate that the genesis of the conflicts is more political than how it is religious. Boko Haram attracted broader concerns of the international community, especially after the 2011 bombing at the United Nations building in Abuja, Nigeria's center of administration. Since then, a sequence of catastrophic bombardments is being carried out by the sect on a semi-daily basis until today.

Although following the outbreak of this strife, thousands of Christians are said to lose their lives, notwithstanding the incidence that dominates the northeast, which is dominant, occupied by the Muslim majority. During this ongoing chaotic anarchism, tens of thousands of peoples - Muslims and Christians alike - were seemingly being butchered, graved alive, tortured, and misplaced or kidnapped. Secondly, the last 2011 elections were almost equally divided the country into two sides. 
Northerners were protesting against the winning of the then Ijaw man, Jonathan, who hails from the Niger-Delta region of the Southern corner of the country. Not because of his barely winning the position, but simply because they were convinced that the elections were full of rigging and fraudulence. On the one side, many interrogations were concluded by domestic as well as foreign investigators that regional politicians seem to have a hand in sponsoring the atrocities of the sect ${ }^{2}$. On the other side, even though the sect uses religious intervention to justify its deadly abhorrent crime but there is no clear link found between the sect and a prominent Muslim scholar in Nigeria who stands as a proponent of its ideology. In fact, many scholars like Sheikh Ja'afar ${ }^{3}$ condemned the way Boko Haram operates with clean and solid facts that the sect engages in translating nonIslamic teaching into its activities.

Boko Haram's deadly operation has rigorously started in late 2009 in response to what they considered ungodly aggression by the Nigerian Police in Bauchi. The attempt instigated the group's latent antagonism toward Nigeria's federation. It soon started launching attacks on Police stations in different areas of Bauchi, which later on spread to other nearby states before it finally centralized in Borno state. The first operation carried out by the police led to the arresting nine of their members and confiscating their timely bombing materials.

Over the course of a decade and a half, the sect has grown incrementally and appeared as the biggest security challenge ever faced by the Nigerian state and henceforth neighboring countries: Niger, Chad, and Cameroon. Significantly, Nigeria's efforts to engage the sect to pose a lot of questions in the mind of Nigerians, including: is Nigerian armed forces were ordered to/not launch attacks on the sect? Have they capitulated before the power of the sect, why are Nigerian troops not well-equipped with modern types of machinery to confront insurgents, etc.? Of course, this project will try to answer these and other critically central questions similar to them.

'Boko Haram' is a combination of two words Hausa and Arabic, respectively. Boko in the Hausa language derived from the English word book and Haram is a classical Arabic word that connotes forbidding or sinful. The phrase Boko Haram has connotations of western learning is sinful. The classical version of Boko Haram has essentially claimed to reject the Westernstyle education that seems contrary to the basic teaching of Islam, like the issue of cloud and rain, the theory of Darwinism, etc.(D. Pham \& Karaboga, 2012). The group, however, adduced to avoid the entire Western-products and Western-oriented cultures and values.

Contrary, the group sent a threat message in an open letter to the supreme leader of the Nigerian Muslims, the Sultan of Sokoto Muhammad Sa'ad Abubakar III, in 2013 that there could be possible attacks on Sokoto soil. Sokoto is considered the center of Islamic activities, the seat of Caliphate, and the only state with 100 percent Muslim population in Nigeria. In fact, the attack was definitely carried out by the sect at Marina police station, some five kilometers far away from the Sokoto Sultan palace.

Toward the end of 2016, the Nigerian authorities declared that the Boko Haram atrocities are at their terminal point. The Sambisa forest, which has been the hideout of the sect throughout the confrontation, is captured by the Nigerian troops. Astonishingly, in the subsequence of the Sambisa captivity ensured by the Nigerian army, many attacks and bombardments were witnessed in some other areas in the region. Albeit, this could strengthen the skepticism that political motivations are behind the insurgency(D. Pham \& Karaboga, 2012).

Since the last quarter of 2015, India has clearly offered to share a version of her experience and expertise in fighting insurgency with some African nations, including Nigeria, the power stronghold of West Africa. During India-Africa Forum Summit, the Cameroonian Minister of External Affairs, Mr. Mbella demonstrated the need for bilateral commitments between India and the most affected countries by Boko Haram insurgency: Nigeria, Cameroon, Nigeria, and Chad. India is expected to help in capacity building in the defence sector. This negotiation looks into how to strengthen allied forces between India and Nigeria to combat the dreaded new brand type of ISIS in the zone. Already it was revealed that the Indian government was working on two states of the art hospital in Nigeria to assist victims of terror.

There is no doubt that many studies have been carried out in this area with yet unsatisfied or inadequate attempts to address the rigorous causes of the prolonging Boko Haram insurgency in Nigeria. This research proposes to fill up the putative cleavage in the literature in order to expand the existing knowledge on the subject matter. Boko Haram terrorism and counterterrorism by the Nigerian government are ongoing processes. It's, therefore, very difficult to exactly predict or set a parameter that could guide outcomes flawlessly. Though some facts could be predicted so to be able to make the future direction of conflict more discernible. However, this study examines to what extent India-Nigeria collaboration in fighting Boko Haram could be fruitful in terms of terminating the insurgency and what should the remaining African countries

\footnotetext{
2 The Australian negotiator, Mr. Stephen Davis named the former Chief of the Nigerian Army Staff, General Azubuike Ihejirika and former governor of Borno State, Ali Modu Sheriff some of the Boko Haram's sponsors. He also promises to name other sponsors, who according to him are bigger than Sheriff (The Tribune Newspaper, 28 September 2014).

3Ja'afar was a prominent scholar trained in the Kingdom of Saudi Arabia's Islamic University (Medina). Ja'afar was from Kano, the largest city and center of commerce in northern Nigeria. He was also a prominent scholar and preacher, and well-recognized scholarship in the entire north.
} 
including those in the region learn from Indian style and tactics, and open a new door for further military training inside and outside Nigeria.

\section{ISLAMIC REVIVALISM IN NIGERIA}

Adesoji (2010), postulate that from 1980 down to 2009, Nigeria was lost somewhere between the Maitatsine group and Boko Haram sect. All these two major groups were in the northern dominant Muslim populated area. Apart from these two, various ethnoreligious clashes that resulted in losing thousands of lives and properties become an undeniable tradition of Nigeria. The multi-ethnic and multi-religious configuration of Nigeria largely accounts for the incessant ethnoreligious imbroglios experienced in the nation for over three decades since the 02nd Republic in 1979.

The country had hardly survived the ethnoreligious crises when the Boko Haram problem violence erupted in 2008. The Boko Haram insurgency, with all its destabilizing propensities, is another challenge of serious concern for which the Federal Government of Nigeria is yet to find the solution. By the eighteenth and early nineteenth centuries, a significant Muslim scholar named Usman Ibn Fodio emerged in a city in the far northwest of Nigeria, Sokoto. Ibn Fodio revived Islam in the entire northern part of Nigeria. His efforts reached and terminated at Ilorin, a city in modern Kwara, one of the thirty-six states in Nigeria. His preaches gave a solid genesis upon which many Nigerian scholars build off their da'wah until today.

\section{BOKO HARAM'S IDEOLOGY: THE ISLAMIC VALUES VERSUS POLITICAL INTERESTS}

All of Adeonipekun, Adeniyi, Akinsoji, and Eden (2016), J.-P. Pham (2012), and Margolin (1978) ideally stressed that there is a similarity in the thinking of the youths and that of the Diaspora on the roots cause of the Boko-Haram crisis. Much of the terrorist behaviors are a response to the frustration of various political, economic, and personal needs or objectives. In Nigeria, criminality cannot be divulged from the frustration-aggression of some concern citizens, ethnic groups, and political interests. Specifically, the case of Niger Delta militancy, bombing, pipeline vandalism, kidnapping, and destruction of oil installations is borne out frustration-aggression of the local authorities.

The formerPresident Goodluck Jonathan's declaration in January 2012 that Boko-Haram has infiltrated his cabinet, most notably the security apparatus, did support not only the conspiracy theory but also supported Ajani, Tope, and other respondents that share the views of different forces that are committed to disintegrate Nigeria. This supported the view that although the root cause might be political, it was not related to the emergence of President Jonathan in 2011. To them, despite the importance of Nigeria and the significance of the challenge it faces, what is actually known and reported is amazingly limited.

Some of the analyses can, at best, be described as wishful thinking - such as the frequently reported, but never confirmed, divisions within Boko Haram between followers of the slain Mohammed Yusuf who wanted to focus on the transformation of Nigeria into their version of a Shari'a-compliant state and those who believe that the state must first be brought down. Moreover, the Nigerian federal and state governments need to do more to build relationships with one another and with the local communities in which Boko Haram operates if they are to acquire the type of actionable intelligence needed to prevent future attacks (Margolin, 1978).

Preventing attacks carrying out by Boko Haram assailers in this part of the country must be organized through some similar dimensional approaches used by the group. Boko Haram group rejected with prejudice what it sees as Western-based warfare that threatens traditions, values as well as customs and beliefs of the classical orientation of northern Nigerian Muslims. The group, however, accuses the West of waging war against Islam (Forest, 2012), which is the dominant religion in the region. The Boko Haram's ideology, therefore, can be traced back to the pre-colonial era somewhere in the early 20th century when the British government attempted a successful trial to enforce its administration in what was known as Kasar-Hausa as well as (Hausa land/northern Nigeria) till 1960 when the governing affairs of the newly independent populous black-African country were handed over to the indigenous people (Margolin, 1978).

Since ever before, the northeast was known to be a paramount part of the Kanem Borno Empire. This Empire had been founded somewhere in mid of the 9th century and lasted till the early 19th century. Massively, vast land, from northeast Nigeria, Chad, Cameroon, Niger, and Libya, had therein fallen under the sole controlled of Kanem Borno. The contact between these areas, especially in trade, made the spread of Islam across West Africa and remaining Sub-Saharan Africa much easier. Islam becomes the religion of the Empire somewhere towards the end of the 11th century during the time of King Seif Umme ibn Abdul Jaleel, and therefore, Kanem Borno Empire was an Islamic state since that time (Encyclopaedia Britannica). The Fulani revivalism under a great scholar, Uthman ibn Fodio whose center was therein in Gobir later known as Sakkwato (Sokoto), challenged the suzerainty of el-Kanemi in Borno. The dispute was later on resolved on the ground of the Islamic interest, which prioritizes unity among the Muslim Ummah, under a single leadership of Islamic law, code of conduct, etc. is one, however. 
Boko Haram centralizes in Borno pretends to pursue its propaganda of safeguarding Islamic teaching and practicing. According to Loimeier (2012), Boko Haram, as a radical group, is not the pioneer movement that advocated Jihad in the region via the means of armed struggle. The group ostensibly tries to portray and follow up the steps of Uthman ibn Fodio in removing the badly corrupt leadership paving the way for the theological ruling system in the land looking at scholars, ulama, the most qualified to govern. However, ulama legitimize their capacity by religious debates and argumentations. Since that time, recourse to theological debate becomes the sine qua non for any political action among Muslims throughout northern Nigeria (Loimeier, 2012).

\section{INDO-NIGERIA EFFORTS MULTIPLICATION IN FIGHTING BOKO HARAM}

Regardless of contemporarily economic, political, and diplomatic challenges, relations between India and Nigeria are friendly. Since ever before, the two countries have been in cordial connection for many decades. These connections have been for tens of years, concentrating on economy, trade, and investments as well as diplomacy together with Indian Diaspora in Nigeria and very limited focused on security. Now, with the expanding Indian quest for energy in Nigeria due to its nature of industrialization, it is, however, a timely engagement to concentrate much deeper on security and military-related dealings.

Indian Prime Minister has in 2007, paid a state visit to Abuja, and met with his counterpart, Umar Musa Yar' Adua, the Nigerian President (between 2007 and 2009-2010), where MoU on security and defense cooperation was ratified between the two countries. Consequently, the Indian government has so far "donated communication equipments worth millions of dollars to Nigerian armed forces. Nevertheless, it set up equipped IT labs in both NDA and CSC" (Beri, 2013). These modern IT labs are used to provide and or propose a solution to recent human and social crimes, including the insurgency type challenging the peace of countries like Nigeria.

Information and Communication Technology (ICT) that consists of hardware, software, and media including the collection, storage as well as transmission of voice, text, and images, can be divided into Information and Communication Infrastructure (ICI) and Information Technology (IT) (Oludare, Omolara, et al., 2015). India is one of Asia's IT power-based nations. So, the bilateral defense agreement signed by both India and Nigeria, including IT capacity to the Nigerian military, is in the line of terminating the Boko Haram insurgency in the country. More secured Nigeria would give much courage to Indian companies to operate in Nigeria without security hesitation.

Defense and military collaboration between Nigeria and India is neither a new set of activities. During the 1960s and 1980s, India had been so much active in supporting Nigeria's defense sector. Many Nigerian army officers including some notable heads of state, such as Major-General Muhammad Buhari, General Babangida, Garba Duba, etc. received their military training in India. In the post-Independence Nigeria, India played unforgettable roles in Nigeria's defense institutions. During the 1960s, it was India that deeply helped in establishing Nigerian Defence Academy (NDA) and Command Staff College at Jaji, all in Kaduna State (Loimeier, 2012).

Collaborative fighting against Boko Haram is one of the most precious points prioritize by the Nigerian authorities. Henceforth, both India and Nigeria have much to do in fighting the insurgency as it means a lot for their individual as well as mutual benefits. For so many decades, large numbers of Indians engage in different professions settle in Nigerian six geopolitical zones including in the northeast.

Nigeria is a home of many natural resources, most of which India quests for. Apart from oil and gas that vastly station in the Niger-Delta region of the country, and that also champion over other means of income in terms of annual GDP per capita, other tremendous resources that could determine prosperity for many countries including India are yet exist in the northern part of Nigeria. The aforementioned details remain solid to concrete bilateral closeness so to propose new sets of visionary agendas which can be realized by both Nigeria and India including peace and security, which are the most important agendas not only to Nigeria but also to India as thousands of Indians settled in a different part of Nigeria including in northeast, for multiple legitimate reasons.

Northeast, the Boko Haram hideout saddles on the huge amounts of coal stone. The coal attracts several foreign firms, including Jindal Power and Steel. Jindal, which is an Indian firm, moves ahead to engage the Nigerian government through what is seen revitalizing the mining techniques in the country (Ezeamalu, 2014). Albeit, the deal, if ratified, could potentially bring about some environmental disturbances, regardless of the prospective omen for both nations, India might need to strengthen its intelligence cooperation with Nigeria, so tackle off a crisis that engulfs the region. The environmental challenges that are rated negatively as a result of mining have already been noticed in some parts of the country. In Enugu, for instance, the mining promotes a dirty atmosphere, that constantly affects local communities and their immediate needs (Ezeamalu, 2014).

Joint intelligence between India and Nigeria to fight the Boko Haram insurgency would pave the way and open another window for trade and diplomatic understandings. This attempt contains a sort of probability that could turn Nigeria into a soft- 
landing trade partner to India and Indian firms as well as Diaspora. Furthermore, India has huge interests in the ECOWAS West African countries and the Gulf of Guinea. These interests largely have to do with peace and a conducive environment reliable for businesses. On the other hand, Boko Haram lethally dark operations hamper economic development as they also seize peace among the peoples and thwart day to day activities.

In the diplomatic phase of it, India's mission in Abuja and Lagos covers its diplomatic affairs with Chad, Cameroon, and the Benin Republic. However, fighting terrorism has links not only with security but also with trade and diplomacy. Vanguard newspaper reported the then Indian envoy to Nigeria as saying; India is sentimentally ready to supply absolute support to the Nigerian government on its war against terror and other forms of security challenges that become severely and dangerously disastrous in recent time (Agbakwuru, 2015).

\section{THE INDIAN STRICKEN EXPERIENCE}

Similarly, according to Morgan (2015), New Delhi, in her side, has already shown commitment in combating the acts of insurgency through sharing her extensive experience in the group's kind of operations. It is quite understandable for a country like India to master fighting the insurgency. India, on more than one occasion, faced a range of attacks as well as threats from groups believed to have similar ideology with Nigeria's home-grown militias such as Indian Mujahideen (IM).

Indian Mujahideen (IM), a 2007-born and home-branded group, claims to base its operation upon assent to incept a Caliphate that can regulate the Islamic Affairs throughout the Indian Sub-continent or South Asia with its center of administration in India. British Broadcasting Cooperation (BBC) has in 2013, compiled a report indicating that the organization was first inspired by the Student Islamic Movement of India (SIMI) (BBC, 2013). Like Boko Haram, IM has claimed several innocent lives of both Indians and foreigners since its establishment.

In yet another similar case facing by New Delhi is a new phase of Shari'ah implementation wave by the Levant in West Asia and the Mediterranean that comprises Syria and Iraq popularly known as ISIS. India, the populous and the most robust economy across South Asia sub-region, is a home of nearly 300 million Muslims. The lethal activities of the Islamist fighters in Iraq, Syria, and elsewhere within the Arabian Peninsula are becoming a threat to the sovereign being of India in both economic and democratic sides. Millions of skilled Indians workers are in the Gulf and other Arab countries. Islam is not a new ideology in the India Sub-continent. Trade and investments had been recorded between Arabs and Indians many years, even before the arrival of Islam. Besides, for hundreds of years, Islam, soon after its arrival, becomes the religion of a large number of Indians (Morgan, 2015).

Perhaps, this might permit expansionism of ISIS toward some areas of the Indian Territory in an advanced manner. Timsit (2019), reported that the ISIS has recently claimed a zone in the Kashmir area and named it Wilayat al-Hindi or Indian province. This announcement followed by a clash between Indian forces and ISIS fighters that resulted in the killing of Ishfaq Sofi, an Indian militant with a connection to ISIS.

\section{CONCUSSION}

Like many countries, India has joined the bloc of suffered states at the hands of terrorist groups. India's counterterrorism activities that have been in place for many years extend to determine its foreign policy towards different countries, especially the ones that fall victim to insurgent activities such as Nigeria. Combating terrorism and insurgency has become another strategy of building new friendship or maintaining the one on the place. India and Nigeria are in diplomatic exchange for so many decades ago that led to economic, trade and investments, culture and political closeness. Over time, Nigeria faced severe challenges by Islamists such as Maitatsine in the 1980s, Shi'ites, and Boko Haram in recent times. India, with its rich experience that has been developed over the years, could be in a position to provide operational caliber to wipe Boko Haram off the existence finally. The trade and investments are the very factors that specifically, cement between the two populous countries

\section{REFERENCE}

Adeonipekun, P. A., Adeniyi, T. A., Akinsoji, A., \& Eden, D. (2016). Floral Diversity and Antibacterial Properties of Honey from Three Different Eco-zones in Nigeria. Bee World, 93(3), 68-73.

Adesoji, A. (2010). The boko haram uprising and Islamic revivalism in Nigeria. Africa spectrum, 45(2), 95-108.

Agbakwuru, J. (2015), "India Pledges to train Nigerian Security in Intelligence Gathering", Vanguard, Abuja, 11th July 2015. BBC, (2013), "Profile: Indian Mujahideen", 29 August, 2013.

Beri, Ruchita (2013), "India-Nigeria Relations: On the Upswing", [Online: web] Accessed 3rd Feb., 2019 URL: https://idsa.in/africatrends/india-nigeria-relations-on-the-upswing_0613.

Encyclopaedia Britannica, (2019), "Kanem-Bornu, Historical Empire Africa" Accessed 17 January, 2019 URL: https://www.britannica.com/place/Kanem-Bornu. 
Ezeamalu, Ben (2014), "Group tells Nigerian Government to be Wary of Coal Mining deal with Indian Firm", Premium Times, Abuja, 03rd April 2014.

Forest, J. J. (2012). Confronting the terrorism of Boko Haram in Nigeria (No. JSOU-12-5). JOINT SPECIAL OPERATIONS UNIV MACDILL AFB FL.

Loimeier, R. (2012). Boko Haram: The development of a militant religious movement in Nigeria. Africa Spectrum, 47(2-3), 137-155.

Loimeier, R. (2012). Boko Haram: The development of a militant religious movement in Nigeria. Africa spectrum, 47(2-3), 137-155.

Margolin, G. (1978). Relationships among marital assessment procedures: A correlational study. Journal of Consulting and Clinical Psychology, 46(6), 1556.

Morgan, K. (2015). Smart specialisation: Opportunities and challenges for regional innovation policy. In: Taylor \& Francis.

Oludare, A. A., Omalara, O. E., Umar, A. M., \& Kemi, D. V. (2015). The use of ICT tools in tackling insecurity and terrorism problem in Nigeria.

Pham, D., \& Karaboga, D. (2012). Intelligent optimisation techniques: genetic algorithms, tabu search, simulated annealing and neural networks: Springer Science \& Business Media.

Pham, J.-P. (2012). Boko Haram's evolving threat: Africa Center for Strategic Studies Washington, WA.

Timsit, Annabelle (2019), "ISIS claims it has established a new "province" in India", Quartz, New Delhi, 11. 